\title{
Using ArcGIS hydrologic modeling and LiDAR digital elevation data to evaluate surface runoff interception performance of riparian vegetative filter strip buffers in central lowa
}

\author{
M. Shrivastav, S.K. Mickelson, and D. Webber
}

\begin{abstract}
The Midwest is well known for agriculture, and Iowa is a leader in corn (Zea mays L.) and soybean (Glycine max [L.] Merr.) production. Fertilizers and chemical pesticides used to increase crop production can adversely affect the soil and water health. Midwest farmers also produce livestock and graze cattle on pastureland that can lead to excessive surface runoff and soil erosion. Establishing vegetative filter strips (VFSs) along the edge of farmland is one of the best management practices (BMPs) to reduce nutrient and sediment loss. However, studies have revealed that the classic VFS design along the length of an agricultural field does not adequately address nonuniform flow through the buffer. New designs are being researched to increase the efficiency of the VFS. In order to accurately implement new design strategies, the runoff flowpaths into the VFS need to be accurately modeled. This research assesses the performance of existing established VFS buffers of selected sites by modeling and analyzing the flow accumulation from the field into the VFS using geographic information system (GIS) and light detection and ranging (LiDAR) derived digital elevation model (DEM) $5 \times$ $5 \mathrm{~m}$ data. This study also employed the new coefficient of flow interception (CFI) approach that improves the process of identifying areas where flow is concentrated and designing more efficient filter strips to account for concentrated runoff. In this study, the performance of VFS in three sites was evaluated by developing and using the CFI. Among the three sites, site 1 had very poor efficiency and no flow passes through the VFS, site 2 had low efficiency, and site 3 had excellent efficiency.
\end{abstract}

Key words: best management practices (BMPs)—coefficient of flow interception-digital elevation model-light detection and ranging (LiDAR) — nonpoint source pollutionvegetative filter strip

\begin{abstract}
Water is necessary for the survival of most living things and is important for domestic, industrial, and agricultural purposes by mankind. Today, there is enormous concern about the quantity and quality of fresh water because of its scarcity due to overuse and pollution. The issue of water quality is currently of greatest concern for the world as polluted water is causing alarming death rates for aquatic organisms, human health hazards, and the aesthetic qualities of many water bodies. Water pollution throughout the world is affecting food chains and food webs and is a growing problem in our envi-
\end{abstract}

ronments. Due to the increasing hazardous consequences related to water quality, awareness to conserve water resources is spreading globally. With respect to growing public concern and awareness to reduce water pollution, the US Congress enacted the 1972 Clean Water Act (CWA), with a motive to protect and enhance the surface water quality in the United States. As a requirement of CWA 303 (d), the US Environmental Protection Agency (USEPA) has identified more than 40,000 water bodies nationally that exceed the maximum pollutant limits of CWA water quality standards (USEPA 2013).
The two primary types of pollution that enter the water environment are point and nonpoint source (NPS). Agricultural production and NPS (diffuse) pollution are very closely related. In farming areas, NPS pollution includes pesticides, fertilizers, animal manure, and soil washed into streams during rainfall-runoff events. All of these various pollutants can degrade the surrounding environment. However, one way of controlling the loss of agrochemicals and soil sediments into receiving water bodies from farmland can be accomplished by planting tall, close-growing stiff grasses or other perennial vegetation in a linear area known as a vegetative filter strip (VFS) buffer. These VFS buffers are bands of planted or indigenous vegetation situated downslope of cropland or animal production facilities to prevent erosion and filter nutrients, sediments, and other pollutants from agricultural runoff before it can reach the nearby water sources (Dillaha et al. 1989). According to the USDA Natural Resources Conservation Service (NRCS), VFS buffers are vegetated land areas of either planted or indigenous vegetation used for minimizing the amount of sediments and contaminants entering a nearby water body carried by runoff from agricultural land or animal production facilities. These best management practices (BMPs) are considered to be an effective measure in reducing the sediment delivery from overland flow by retarding the runoff velocity and filtering sediment (Van Dijk et al. 1996).

Many efforts have been made to minimize NPS pollution from cropland and to reduce off-site impacts by reducing erosion and surface runoff within fields. When flowing across the VFS, surface runoff undergoes changes in composition and volume, entering the watercourse relatively cleaner than when it left the field (Abu-Zreig et al. 2004). The VFS buffer acts as a barrier to the movement of the suspended particles and decreases the velocity of flow in the run-

Manish Shrivastav is a PhD candidate in the Agricultural and Biosystems Engineering Department at lowa State University, Ames, lowa. Steven K. Mickelson is department chair and professor in the Agricultural and Biosystems Engineering Department at lowa State University, Ames, lowa. David Webber is an associate professor in the Agricultural and Biosystems Engineering Department at lowa State University, Ames, lowa. 
off, which in turn promotes settling of the suspended particles. The sediment of sizes typically greater than $40 \mu \mathrm{m}$ can be captured easily. However, the remaining small size primary particles and aggregates are difficult to remove by filtering because there is still the presence of some relatively low turbulent energy in water sufficient to keep these sediments in suspension (Gharabaghi et al. 2001). Dosskey et al. (2002) concluded that the efficiency ofVFS decreases with increasing flow concentration. This BMP also requires timely maintenance to maintain its effectiveness over time. Several studies have been conducted to assess the effectiveness of VFS buffers in reducing sediments and nutrients from runoff. The effectiveness of a VFS buffer depends on the length, types of vegetation, age, level of development, and most importantly, flow interception capacity of the VFS buffer. The quantification of a surface flow interception coefficient for a VFS buffer will help to quantify the amount of sediments and chemicals removed from runoff.

The effectiveness of a VFS is determined by several factors such as the VFS length, slope, and vegetation species, as well as the sediment size distribution and chemical concentration in the runoff. The length of the VFS is considered to be an important factor affecting sediment removal efficiency. Several studies have shown that increasing the flow length beyond $10 \mathrm{~m}$ has very little effect in increasing the efficiency of a VFS (Gharabaghi et al.2001; Lee et al. 2003; AbuZreig et al. 2004). A study conducted by Ree (1949) on grass filters of lengths 1,4 to 5 , and $10 \mathrm{~m}$ showed a filtering efficiency of $50 \%$ to $60 \%, 60 \%$ to $90 \%$, and $90 \%$ to $99 \%$, respectively. Gharabaghi et al. (2001) studied the sediment removal efficiency of a VFS on varying lengths of $2.44 \mathrm{~m}$ to $19.52 \mathrm{~m}$ for a $1.22 \mathrm{~m}$ wide field with a slope of $5.1 \%$ to $7.2 \%$ and concluded that the first $5 \mathrm{~m}$ were significant in removing suspended solids and aggregates greater than $40 \mu \mathrm{m}$ in runoff. The experiment conducted by Abu-Zreig et al. (2004) in 20 fields with filter lengths of 2, 5, 10 , and $15 \mathrm{~m}$ and slopes of $2.3 \%$ to $5 \%$ concluded that there is no significant increase in sediment removal efficiency with greater than a $10 \mathrm{mVFS}$ length. The area ratio (AR) of the cropland drainage area to the VFS area is one of the important factors that affects the efficiency of VFS. Greater AR allows a larger volume of flow through smaller sections of VFS, thus lowering the efficiency of VFS in filtering the pollutants and sediments from runoff. Past studies by Arora et al. (2003) and Leeds et al. (1993) suggest that AR between 1:1 and 8:1 can achieve excellent sediment retention. According to Leeds et al. (1993), AR should be maintained less than 50:1 for good sediment retention. However, Arora et al. (2003) found that while higher AR values tended to relate to lower sediment removal efficiency, there wasn't a significant difference in VFS performance.

Several studies have suggested that infiltration is the primary mechanism responsible for trapping the suspended solids and applied chemicals (Ree 1949; Meyer et al. 1995; Gharabaghi et al. 2001). The submergence of vegetation also can result in a decrease in Manning's coefficient $(n)$, which in turn significantly decreases the efficiency of aVFS (Ree 1949; Van Dijk et al. 1996). The flow retardation and infiltration were more efficient with older grass species (Van Dijk et al. 1996) since this denser vegetation provided more resistance to flow velocity, resulting in an increased contact duration between runoff and vegetation. Consequently, this led to less erosive power and transport capacity of the runoff, resulting in an increasedVFS sediment trapping efficiency.

Sediment size distribution is also an important factor that determines the efficiency of a VFS. Studies have concluded that smaller-sized sediments require a longer settling time, therefore requiring a longer vegetative filter length (Meyer et al. 1995; Gharabaghi et al.2001). In a study conducted by Abu-Zreig (2001), trapping efficiencies of $0 \%$ and $47 \%$ were observed over filter lengths of $1 \mathrm{~m}$ and $15 \mathrm{~m}$, respectively, for clay particles. Lee et al. (2003) conducted an experiment to study the effectiveness of a multispecies riparian vegetative buffer in removing NPS pollutants from cropland runoff. The experiment involved installing three plots where each of the cropland source areas was matched with a no buffer (control), a $7.1 \mathrm{~m}$ switchgrass (Panicum virgatum) buffer, and a $16.3 \mathrm{~m}$ switchgrass/woody plant buffer. Sediment removal efficiencies of $95 \%$ and $97 \%$ were observed for switchgrass and switchgrass/woody plant buffers, respectively. The increased sediment removal efficiency of the switchgrass/woody plant buffer was determined to be the additional vegetative buffer length that increased infiltration. The ratio of sediment transported through the "control" plot to sediment transported through the switchgrass buffer was 13:1. Particle size distribution in surface runoff changed as runoff passed through the VFS buffer. In this case, large particles were deposited before small particles, and more than $90 \%$ of the sediment in surface runoff from the buffered plots was in the $<0.05 \mathrm{~mm}$ size fraction. During the infiltration of nutrients, suspended fine particles with adsorbed chemicals also entered the soil profile, thus decreasing the surface runoff and sediment transport capacity.

The performance of VFS buffers in removing pollutants from runoff also largely depends upon the type of flow. Factors like concentrated flow or a nonuniform distribution of flow limit the performance of a VFS. Generally, a uniform flow distribution (sheet flow) helps to achieve higher pollutant removal efficiencies. Undulating surfaces and slopes $>6 \%$ cause concentrated flow, erosion, and decreased sediment removal efficiency of theVFS buffer. When the flow is concentrated, the velocity of runoff becomes too high to be effectively treated by a VFS. Dosskey et al. (2002) found that the concentration of surface runoff from agricultural fields can significantly restrict the efficacy of riparian buffers to remove pollutants. Riparian buffer evaluation plots on four farms were used to study the influence of surface runoff on sediment trapping efficiency. A numerical model using a regression equation based on the proportion of buffer area to contributing field runoff area (buffer area ratio) was used for evaluating the sediment trapping efficiency. The model yielded sediment trapping efficiencies of $99 \%, 67 \%, 59 \%$, and $41 \%$ for uniform flow conditions and 43\%, 15\%, 23\%, and $34 \%$ for nonuniform flow conditions for the four fields, respectively.

Site conditions play a key role in the performance of a VFS buffer and should be considered when assessing a VFS. Gilliam et al. (1993) observed that pesticides are less adsorbed in the shallow vadose zone. The direction and rate of chemical movement is greatly dependent on whether the underlying layer is permeable or impermeable. If permeable, chemicals can flow in a vertical direction and leaching is more pervasive. However, if the layer is impermeable, this would contribute to the lateral flow of shallow ground water and hence will result in polluting the surface water.

The primary objective of this study was to evaluate the performance efficiency of 
currently installed riparian VFS buffers by modeling and analyzing the flow accumulation from the field in the VFS using geographical information systems (GIS) and light detection and ranging (LiDAR)derived high-resolution digital elevation model (DEM) data. The DEM data sets used in this study were generated by resampling an airborne sensor-derived LiDAR $1 \times 1 \mathrm{~m}$ DEM to a $5 \times 5 \mathrm{~m}$ LiDAR DEM to minimize the file size of the data sets and possibly improve the computer computational proficiency in handling the data sets. Also, this study included the development of the coefficient of flow intercept (CFI) equation, which was applied to three selected Rock Creek watershed research sites.

\section{Materials and Methods}

Research Sites. This study focused on three agricultural subbasin field sites located in the Rock Creek watershed, Jasper County, Iowa, United States $\left(41^{\circ} 46.211^{\prime}\right.$ N, 92 ${ }^{\circ} 50.330^{\prime}$ W) (figure 1). This watershed drains into Rock Creek Lake, which is a major recreational attraction for residents of central Iowa. However, the water quality of Rock Creek Lake has been at risk due to incoming sediment and nutrient transport from contributing agricultural field surface runoff and stream channel flow. The study area included three row crop research sites with established vegetative buffers and other conservation BMPs in Jasper County from which runoff may contribute to the quality of water in Rock Creek Lake, and will be identified as sites 1,2, and 3. Each of these sites were subdivided into multiple subbasin field areas. The transportation of sediment and chemicals from these fields, primarily established as two-year crop rotations of corn (Zea mays L.) and soybean (Glycine max L.), has been identified as a possible reason for an algal bloom causing low oxygen $\left(\mathrm{O}_{2}\right)$ levels that adversely affect aquatic life in the lake. The riparian VFS buffers were designed by the USDA NRCS in order to help minimize the transport of nutrients, sediments, and pesticides in runoff from the agricultural fields.

Site 1 (figure 2) has a stream running through the center of the research area and flows into Rock Creek Lake. A 35 m buffer was installed on both sides of the stream immediately downslope from the cropland runoff source area. There also are terraces and grassed waterways that divided the site into three subbasin field areas $1 \mathrm{~A}, 1 \mathrm{~B}$, and $1 \mathrm{C}$.

\section{Figure 1}

Location of Rock Creek watershed and field research sites 1, 2, and 3 in northeastern Jasper County, central lowa, United States.

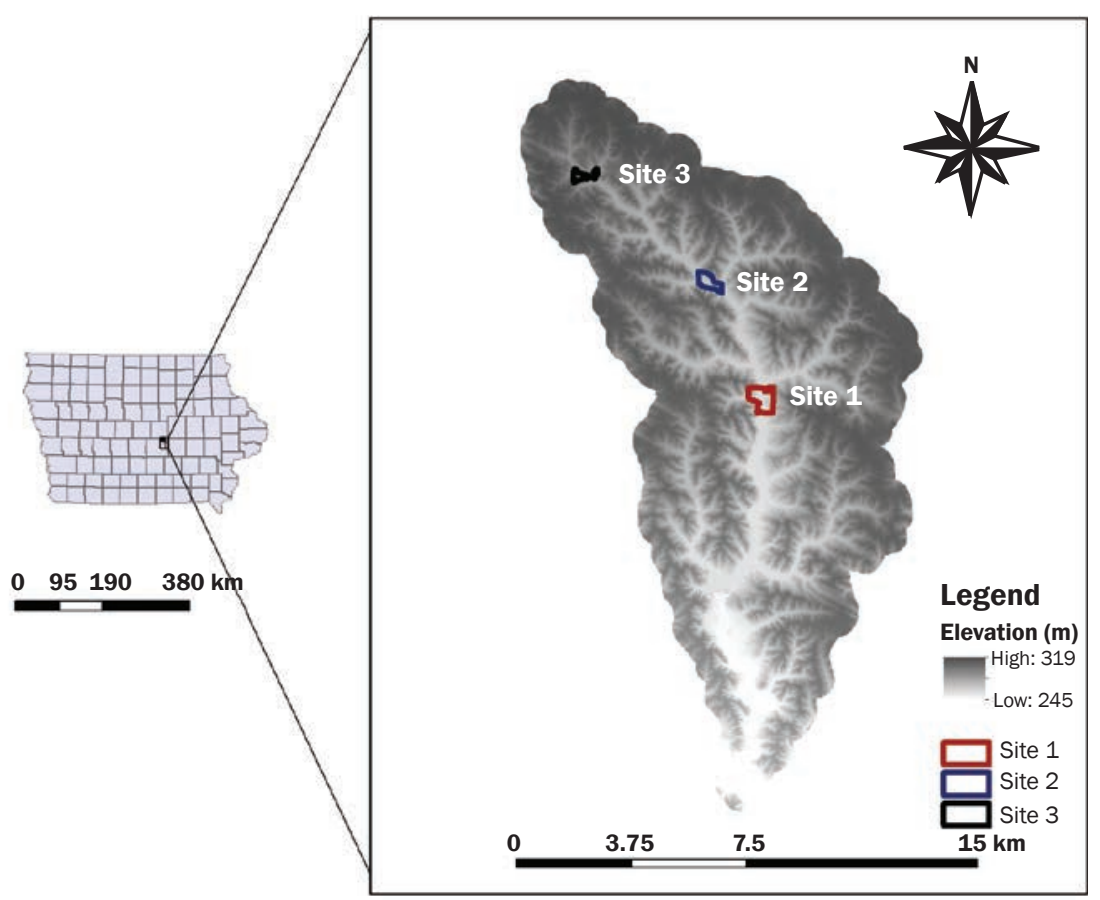

Field surveys of areas $1 \mathrm{~A}$ and $1 \mathrm{~B}$ indicated that only a small portion of surface runoff flowed through the riparian VFS buffers. Some undulations observed in field $1 \mathrm{~A}$ caused the runoff to bypass the buffer and flow toward the natural riparian area south of the subbasin area instead of flowing through the VFS. From site verification, traces of sedimentation also were observed at the leading edge of the VFS buffer, which would only be possible during a larger rainfall event, as the topography of the field shouldn't allow surface flow to be toward the VFS buffer.

Field site 2 (figure 3) was located north of site 1 , and it also had a stream running through it, dividing it into subbasins $2 \mathrm{~A}$ and 2B. An approximately $18 \mathrm{~m}$ wide VFS was installed at the edge of the field on both sides of the stream. It was observed that runoff from the field considerably circumvented the VFS area based on ground-truthed and verified simulated flowpaths.

Site 3 (figure 4) was located in the extreme north headwaters area of the Rock Creek watershed with $30 \mathrm{~m}$ wide VFS buffers on both sides of the stream. Site 3 also included the subbasin field areas $3 \mathrm{~A}, 3 \mathrm{~B}$, and $3 \mathrm{C}$. The presence of a draw divided site 3 into areas $3 \mathrm{~A}$ and $3 \mathrm{~B}$. The adjacent field areas were planted to corn in 2006. Area 3C was located on the northeastern side of site 3 , where it originally included an $18 \mathrm{~m}$ wide grassed waterway.

The major soil association at the research site is the Downs-Tama-Shelby association with silty, silty clay, and loamy soils formed in upland loess and glacial till. Dominant soils at the site are Tama silty clay loam-finesilty, mixed, mesic Typic Argiudolls - and Ackmore silt loam-fine-silty, mixed, nonacid, mesic Aeric Fluvaquents. Minor soils at the site include Colo, Ely, and AckmoreColo complex (Nestrud and Worster 1979). Table 1 includes the soil types and descriptive information of the research sites.

Flowpath Delineation. The research work was performed using ArcGIS and a LiDAR points-generated DEM with a resolution of $5 \times 5 \mathrm{~m}$. The DEM was used to obtain simulated hydrologic surface flowpath and drainage features in ArcGIS 10.3 and 10.4. Both automatic and manual delineation techniques were applied to produce GIS layers of contributing drainage areas.

Methodology. The GIS software was used to spatially validate visual observations regarding surface flow and outlet points in field sites 1,2, and 3. Elevation 


\section{Figure 2}

Subbasin field areas $1 \mathrm{~A}, 1 \mathrm{~B}$, and $1 \mathrm{C}$ of site 1 showing light detection and ranging (LiDAR) $5 \times 5 \mathrm{~m}$ digital elevation model (DEM)-derived flowpaths. VFS is vegetative filter strips.

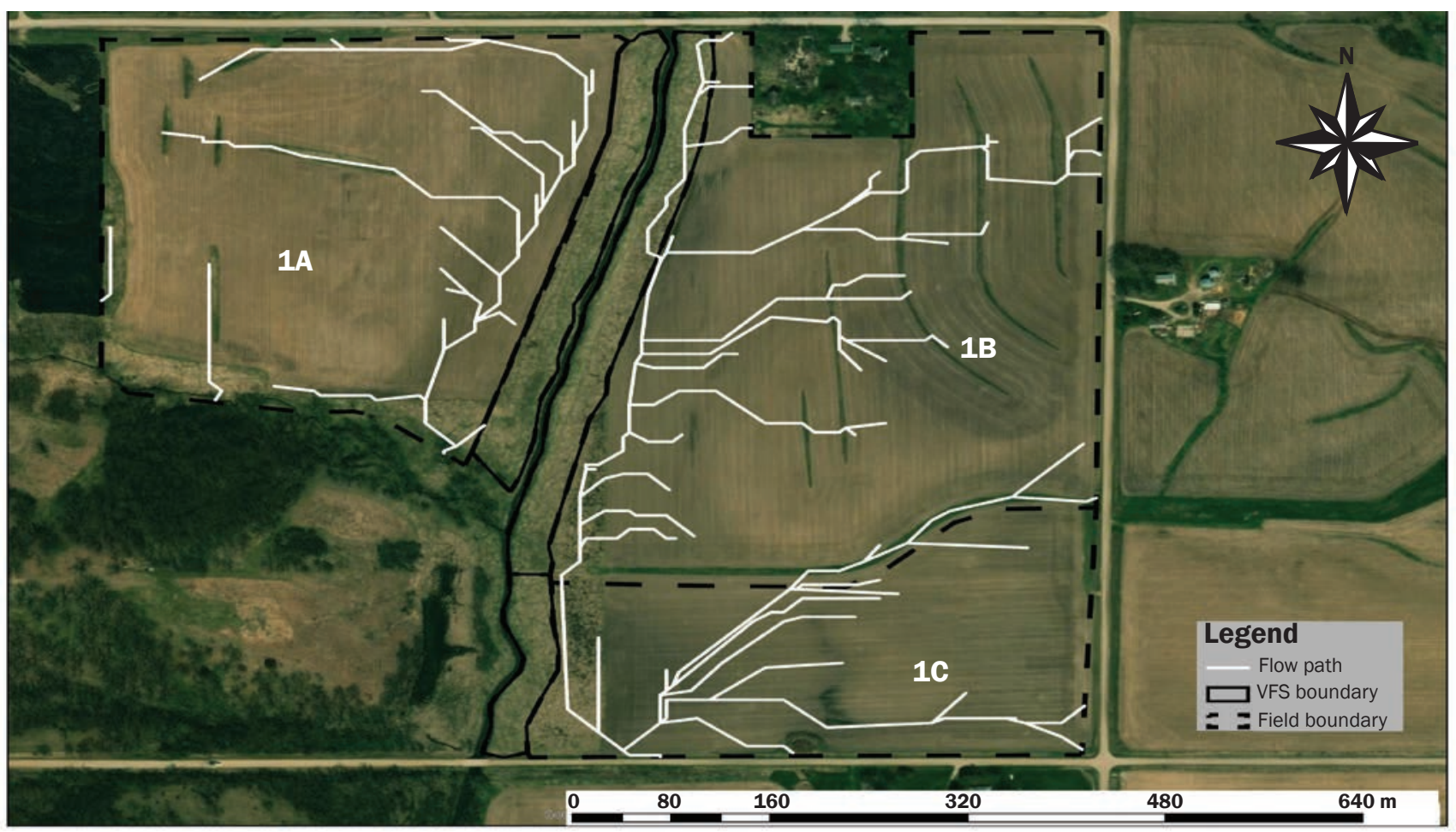

data in the DEM were used to determine flow routing in the fields using ArcGIS version 10.3. The DEM also was used to validate the visual observation regarding surface flow interception of the VFS buffer and to quantify VFS buffer interception efficacy using the CFI in equation 1 :

\section{$\mathrm{CFI}=\frac{\text { Total Area of VFS }\left(\mathrm{m}^{2}\right)}{\text { Drainage Area of Flowpaths Intercepted }\left(\mathrm{m}^{2}\right)}$}

The contributing drainage area and total VFS area were calculated using ArcGIS tools, and the CFI value could be between 0.0 and 1.0. The CFI can be calculated only for those contributing drainage areas whose flowpaths pass through the VFS buffer. To determine whether a flowpath is intercepted by the VFS, the flowpath obtained from the DEM is overlaid on the ArcGIS online basemap for visual observation and also intersecting the flowpath with the VFS boundary in ArcGIS.

The LiDAR DEM was also used in identifying sinks in the topography and generating the flow accumulation and stream network/flowpaths in the watershed using the elevation data. The contributing runoff drainage area was determined by using the automatic delineation tool in ArcGIS. The VFS area was calculated by digitizing over a base map for each site using ArcGIS online images in ArcGIS.

Area Ratio/Coefficient of Flow Interception Calculation and Analysis Stepwise Procedure. The AR is defined as the ratio of total drainage area of all flowpaths to the total area of the VFS. It can be calculated as below:

Step 1. Area Ratio calculation:

$\mathrm{AR}=\frac{\text { Drainage Area of All Flowpaths }\left(\mathrm{m}^{2}\right)}{\text { Total Area of VFS }\left(\mathrm{m}^{2}\right)}$

Step 2. Comparison of AR value to standard AR values (Bansal 2006):

I. Excellent AR, 1:1 to $8: 1$

II. Good to Fair AR, 8:1 to 50:1

III. Poor AR, > 50:1

Step 3. Calculation of CFI is between 0.0 and 1.0 (equation 1) for vegetative buffer interception performance.

\section{Results and Discussion}

The average of the difference in elevation between a $5 \times 5 \mathrm{~m}$ LiDAR generated DEM and a $5 \times 5 \mathrm{~m}$ DEM generated from onsite collected survey data was $14 \mathrm{~cm}$ with root mean square error of $16 \mathrm{~cm}$. The vertical accuracy of the LiDAR generated DEM was found to be $31 \mathrm{~cm}$ using the National Standard for Spatial Data Accuracy method. The site 1 research area is divided into three subbasins: 1A, 1B, and 1C. The flowpaths for the site were delineated to evaluate the effectiveness of the VFS buffer. The LiDAR $5 \times$ $5 \mathrm{~m}$ DEM generated flowpaths that corresponded to those observed during site visits in 2013 and 2014. Figure 2 indicates no simulated surface flow through the VFS due to surface undulations present at the field site, redirecting surface flow toward the south of the watershed instead of passing through the VFS. There were signs of some sedimentation at the leading edge of the VFS, which could be attributed to the runoff from larger rainfall events.

During site verification for subbasins $1 \mathrm{~B}$ and $1 \mathrm{C}$, we observed sedimentation occurring at the downslope end of the grassed waterway present between the two subba- 
sins (figure 2). These results indicate that surface runoff was diverted to an alternate flowpath from the grassed waterway during high rainfall events. Figure 2 shows how surface runoff was diverted from the full length of the grassed waterway in subbasin site $1 \mathrm{C}$. This surface flow was also observed to become more concentrated as it approached the VFS.

Field site 2 was divided into subbasins $2 \mathrm{~A}$ and $2 \mathrm{~B}$ (figure 3 ). The surface flowpaths modeled from the $5 \times 5 \mathrm{~m}$ LiDAR DEM indicated they passed through the VFS at many locations. This corresponded to visual observations made during the field site visits. The simulated surface flowpath pattern suggests that the flow in this site was more dispersed but does become more concentrated as the flowpath approaches the VFS buffer.
Site 3 consists of subbasins $3 \mathrm{~A}, 3 \mathrm{~B}$, and $3 C$ (figure 4). Subbasin sites $3 A$ and $3 B$ are adjacent to each other, with subbasin $3 \mathrm{C}$ located in the northeast corner of the field site. Note that all simulated surface flowpaths pass through the VFS buffer area. Although an adequate sample of on-site/groundtruthed observations could not be obtained due to limited access to research site 3 , geospatial analysis results using simulated surface flowpaths overlaid to high-resolution aerial imagery indicate the flowpaths tend to follow the grassed waterway drainage features. These site 3 flowpath correspondence results were also found in Webber et al. (2018).

These results indicate that the simulated flowpaths are generally representing the actual hydrologic landscape conditions at the research field sites. Some of these hydrologic conditions are quantified as AR and CFI values in table 2.

It is apparent from table 2 that some sites have AR that are fairly good, but the CFI values are lower. In an ideal situation, the CFI values must be equal to the reciprocal of the AR values. Here in some situations, the values of CFI are slightly higher than the reciprocal of their corresponding $\mathrm{AR}$ values. This is because the effective contributing drainage area of the flowpath intercepted by VFS is less than that of the total contributing area. At sites where CFI values are greater than the reciprocal of AR, some of the flowpaths are not intercepted by the VFS and runoff takes an alternate route to reach the nearby water sources without getting filtered. When the LiDAR DEM derived flowpaths were draped on the ArcGIS online basemap for site 1 subwatershed $1 \mathrm{~A}$, it was apparent

\section{Figure 3}

Subbasin field areas $2 \mathrm{~A}$ and $2 \mathrm{~B}$ of site 2 showing light detection and ranging (LiDAR) $5 \times 5 \mathrm{~m}$ digital elevation model (DEM)-derived flowpaths. VFS is vegetative filter strips.

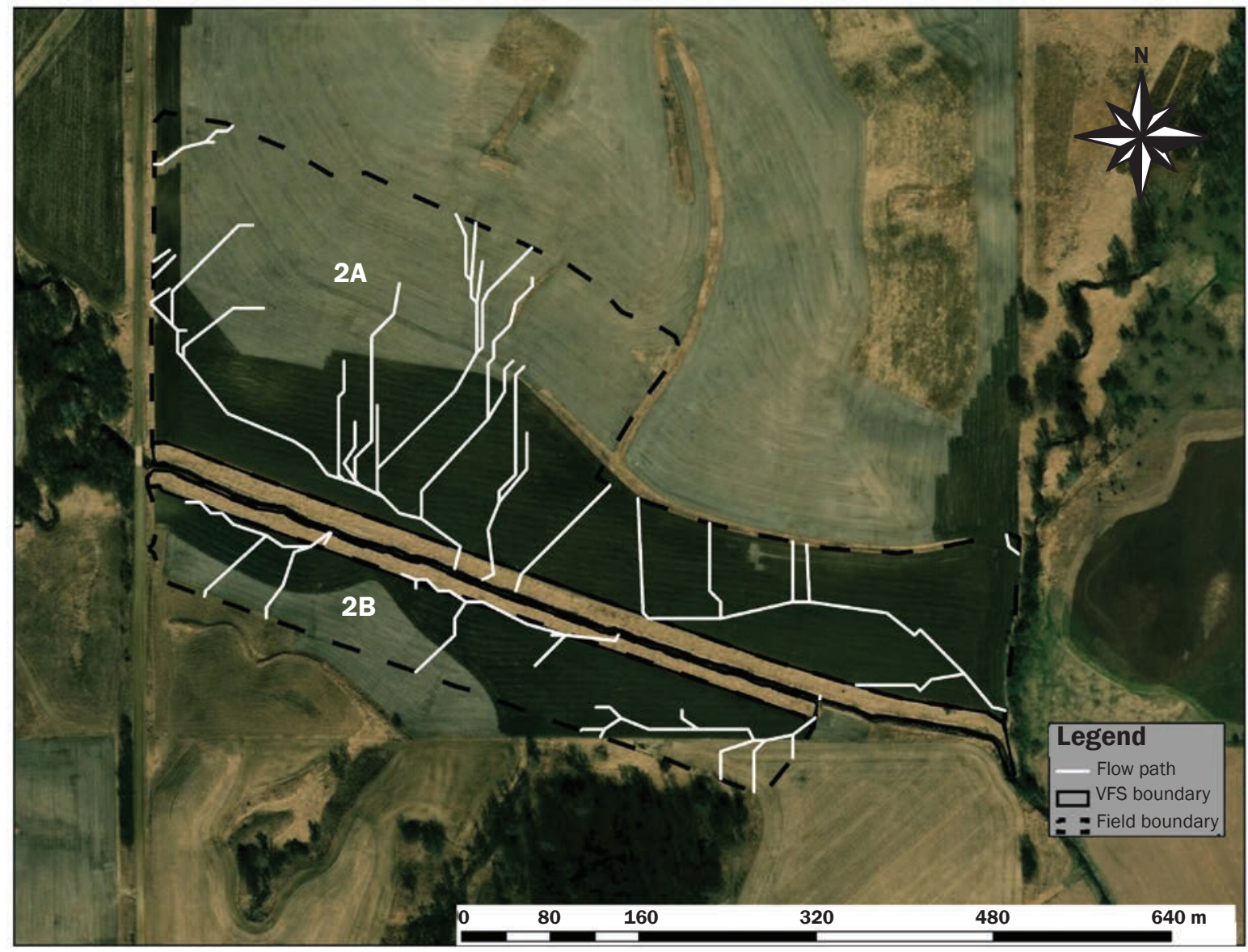




\section{Figure 4}

Subbasin field areas $3 \mathrm{~A}, 3 \mathrm{~B}$, and ${ }_{3} \mathrm{C}$ of site 3 showing light detection and ranging (LiDAR) $5 \times 5$ $\mathrm{m}$ digital elevation model (DEM)-derived flowpaths. VFS is vegetative filter strips.

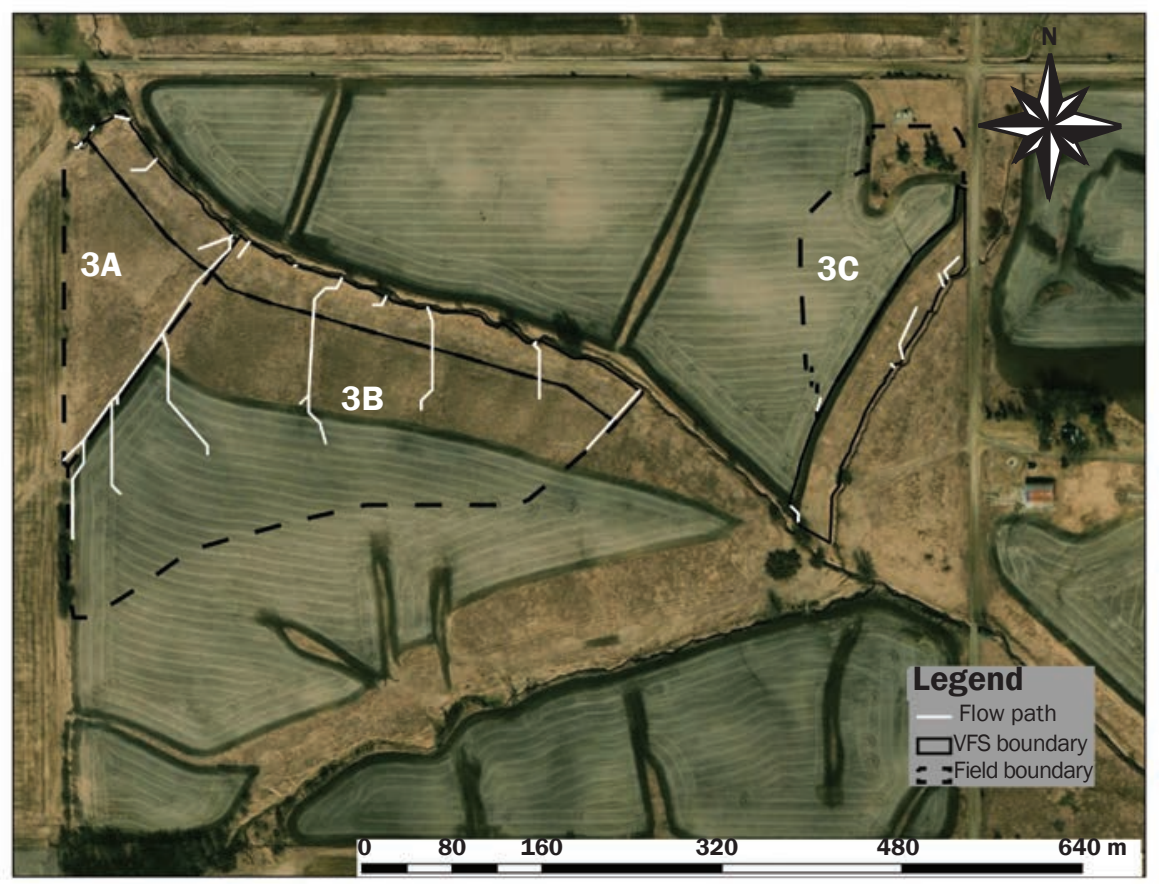

that none of the flowpaths passed through the VFS. This was also validated during the site visits. At sites 2 and 3 the flow is not as concentrated as at site 1 . Most of the flowpaths pass through the VFS. The contributing area of the flowpaths passing through the VFS is less than the total drainage area. From this study it is clear that surface flow can concentrate at some location other than the VFS buffer, and the flow does not necessarily make it all the way to a VFS.

The USDA NRCS had used $30 \mathrm{~m}$ National Elevation Dataset (NED)-DEM data to design, plan, and establish VFS buffers as late as 2014. While comparing the flowpaths derived from the $30 \mathrm{~m}$ NED-DEM and the LiDAR-derived $5 \mathrm{~m}$ DEM, the simulated flowpaths derived from the LiDAR gener- ated $5 \mathrm{~m}$ DEM were more accurate based on visual verification during on-site field visits.

\section{Summary and Conclusions}

The VFS buffers are key elements in reducing pollutants from runoff water and have been used for this purpose for more than two decades. From this study, it can be concluded that the classic VFS design using the $30 \mathrm{~m}$ NED-DEM established along the length of an agricultural field does not adequately address the nonuniform flow through the VFS buffer. From a sample of eight subwatersheds, only three of them have excellent CFI values. One reason for VFSs not functioning as intended, resulting in a diversion of surface flow, might be the deposition of sediments filtered out of the flow over time, causing a surface water incursion and new pathways of flow parallel to the VFS. New technologies such as high-resolution DEM data, ArcGIS hydrologic modeling, and geospatial analysis can be used to improve the design of a VFS and to determine the optimal location for VFS buffers. Periodic visual assessments and repairs of VFS buffer sites also are important to maintain optimal BMP performance. This research can be applied to other watersheds and can be used for finding the optimal location for installing VFS buffers versus the current practice of placing the BMPs along an entire field edge or streambank.

\section{References}

Abu-Zreig, M. 2001. Factors affecting sediment trapping in vegetated filter strips: Simulation study using VFSMOD. Hydrological Processes 15(8):1477-1488.

Abu-Zreig, M., R.P. Rudra, M.N. Lalonde, H.R. Whiteley, and N.K. Kaushik. 2004. Experimental investigation of runoff reduction and sediment removal by vegetated filter strips. Hydrological Processes 18(11):2029-2037.

Arora, K., S.K. Mickelson, and J.L. Baker. 2003. Effectiveness of vegetated buffer strips in reducing pesticide transport in simulated runoff. Transactions of the ASABE 46(3):635-644

Bansal, M. 2006. Vegetative Filter Strip Assessment in the State of Iowa. Master's thesis, Iowa State University.

Dillaha, T.A., R.B. Reneau, S. Mostaghimi, and D. Lee. 1989. Vegetative filter strips for agricultural nonpoint source pollution control. Transactions of the ASAE 32(2):513-0519.

Dosskey, M.G., M.J. Helmers, D.E. Eisenhauer, T.G. Franti, and K.D. Hoagland. 2002. Assessment of concentrated flow through riparian buffers. Journal of Soil and Water Conservation 57(6):336-343.

Gharabaghi, B., R.P. Rudra, H.R. Whiteley, and W.T. Dickinson. 2001. Sediment-removal efficiency of vegetative filter strips. Paper No. 012071. Sacramento, CA: American Society of Agricultural Engineers.

Gilliam, J.W., S.S. Batie, P.M. Groffman, G.R. Hallberg, N.D. Hamilton, W.E. Larson, K.L. Linda, P.J. Nowak, R.E. Rominger, B.A. Stewart, K.K. Tanji, J.V. Schilfgaarde,

Table 1

Selected dominant soil type data, descriptive information, and physical properties at the Rock Creek watershed research subbasin field sites 1, 2, and 3 (Nestrud and Worster 1979).

\begin{tabular}{|c|c|c|c|c|c|}
\hline Research site & Soil series & Soil description & $\begin{array}{l}\text { Bulk density } \\
\left(\mathrm{g} \mathrm{cm}^{-3}\right)\end{array}$ & Clay (\%) & $\begin{array}{l}\text { Permeability } \\
\left(\mathrm{cm} \mathrm{h}^{-1}\right)\end{array}$ \\
\hline 1 & Tama & Fine-silty, mixed, mesic Typic Argiudolls & 1.40 & 18 to 26 & 1.5 to 5.1 \\
\hline 2 & Ackmore & Fine-silty, mixed, mesic Aeric Fluvaquents & 1.35 & 28 to 32 & 1.5 to 5.1 \\
\hline 3 & $\begin{array}{l}\text { Ackmore-Colo } \\
\text { Complex }\end{array}$ & $\begin{array}{l}\text { Fine-silty, mixed, mesic Aeric Fluvaquents; } \\
\text { fine-silty, mixed, mesic Cumulic Haplaquolls }\end{array}$ & 1.35 & 20 to 26 & 1.5 to 5.1 \\
\hline
\end{tabular}


Table 2

Area ratio (AR) and coefficient of flow interception (CFI) value of the sites.

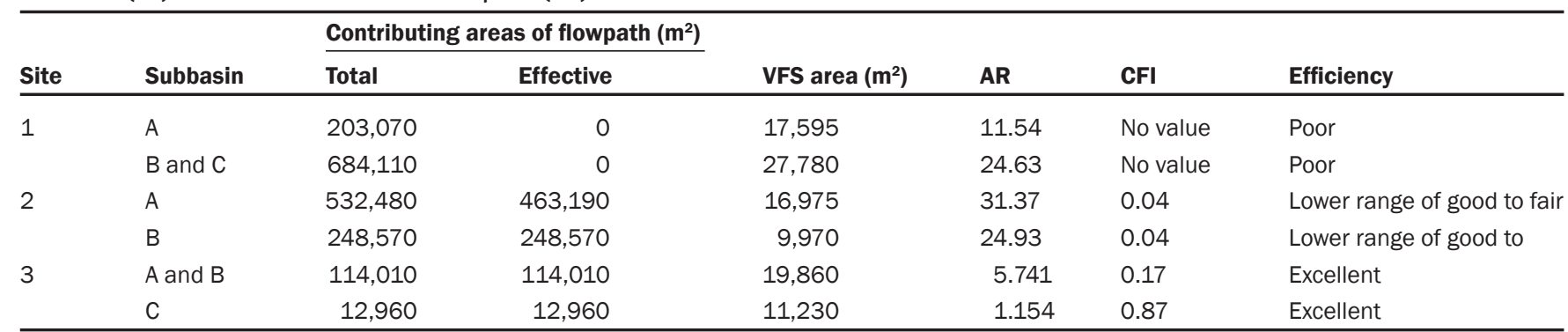

Notes: VFS = vegetative filter strips. CFI range = excellent: 0.125 to 1.000 ; good to fair: 0.02 to 0.125 ; and poor $<0.02$.

R.J. Wagenet, and D.L. Young. 1993. Soil and Water Quality: An Agenda for Agriculture. Washington, DC National Academies Press.

Lee, K.H., T.M. Isenhart, and R.C. Schultz. 2003. Sediment and nutrient removal in an established multi-species riparian buffer. Journal of Soil and Water Conservation 58(1):1-8.

Leeds, R., L.C. Brown, M.R. Sule, and L. VanLieshout. 1993. Vegetative Filter Strips: Application, Installation and Maintenance. The Ohio State University Extension Factsheet (1993). Columbus, OH: The Ohio State University.

Meyer, L.D., S.M. Dabney, and W.C. Harmon. 1995. Sediment trapping effectiveness of stiff-grass hedges. Transactions of the ASABE 38(3):809-815

Nestrud, L.M., and J.R. Worster. 1979. Soil Survey of Jasper County, Iowa. Washington, DC: USDA Soil Conservation Service.

Ree, W.O. 1949. Hydraulic characteristics of vegetation for vegetated waterways. Agricultural Engineering 80(4):184-189

USEPA (US Environmental Protection Agency).2013.Aquatic Life Ambient Water Quality Criteria for Ammonia: Freshwater 2013. Office of Water. EPA 822-R-18-002. Washington, DC: US Environmental Protection Agency. https://www.epa.gov/sites/production/files/2015-08/ documents/aquatic-life-ambient-water-quality-criteriafor-ammonia-freshwater-2013.pdf.

Van Dijk, P.M., FJ.P.M. Kwaad, and M. Klapwijk. 1996. Retention of water and sediment by grass strips. Hydrological Processes 10(8):1069-1080.

Webber, D.F., M. Bansal, S.K. Mickelson, M.J. Helmers, K. Arora, B.K. Gelder, M. Shrivastav, and C.J. Judge. 2018. Assessing surface flowpath interception by vegetative buffers using ArcGIS hydrologic modeling and geospatial analysis for Rock Creek watershed in central Iowa. The 10th Annual ASABE Drainage Symposium “Advances in Drainage" Special Collection. Transactions of the ASABE 61(1):273-283. 